\title{
重症くも膜下出血急性期の病態と治療
}

\author{
佐 藤章
}

\section{Clinicopathological Features and Treatment of Severely Ill Patients with a Subarachnoid Hemorrhage}

by

Akira Satoh, M.D.

from

Neurosurgical Department, Chiba Emergency Medical Center

The pathophysiological features of severely ill patients with a subarachnoid hemorrhage (SAH) due to a rupture of an intracranial aneurysm are described, with special reference to treatment strategy during the acute stage. Although global ischemia must be the predominant damage to the brain, a therapeutic assessment of low grade cases should be made carefully. Patients should be observed for changes in clinical symptoms, which could consist of complex mixtures of cerebral damage such as ischemia, intracerebral hemorrhage, intraventricular hemorrhage, edema and (or) hydrocephalus. A line should be placed between Grade IV and V cases with a Glasgow Coma Scale (GCS) score of 6 and 5, because the outcome of GCS Group 6 is significantly better $(p<0.01)$ than GCS Group 5, and is the same as those of GCS Group 7. There are many patients however with an initial score of GCS score of 5,4 and 3, who can achieve a favorable outcome if proper treatment is provided.

A systemic sympathetic hyperdischarge is another problem during the acute stage. This may often cause serious cardio-pulmonary disorders such as myocardial ischemia, arrhythmias, pulmonary edema or even apnea. This transient, stormy, sympathotonia can be quantitatively assessed by a rapid elevation of both epinephrine and nor-epinephrine in blood serum after SAH. The author has confirmed that the value obtained by dividing the blood glucose level $\left(\mathrm{mg} \mathrm{dL}^{-1}\right)$ by the serum potassium level $\left(\mathrm{mEq} \mathrm{L}^{-1}\right)$ correlates well with changes of serum catecholamine levels. By defining this value as a stress index (SI), and calculating it from the blood glucose and potassium level, one can evaluate the sympathetic tone, and therefore the probability of occurrence of serious systemic complications during an acute stage after SAH.

(Received June 6, 1997; accepted October 9, 1997)

Key words : subarachnoid hemorrhage, poor grade, surgical indication, complications, catecholamines Jpn J Neurosurg (Tokyo) 7:24-31, 1998

\section{はじめに}

脳動脈瘤破裂によるくも膜下出血 (SAH) 重症例の急 性期治療にあたっては, 動脈瘤そのもの, および primary brain damage (PBD)などの頭蓋内病変に対する治療方 針の決定だけではなく，しばしば合併する重篤な呼吸・ 循環器系障害などの全身的な反応への適切な対応が重要 となる4)(12)17)。そこで本稿では，このような重症 SAH 特有の急性期病態を, (1) PBD, (2)出血に続発する全身性
の反応，という両面から検討したうえで，最重症例に対 する具体的な治療方針についての著者らの考えを述べて みたい。

\section{対象および方法}

対象は，1980 年〜1994 年の期間中に，発症後 72 時間 以内に来院したSHA 1,176 症例で, coil embolization については最近の 10 症例を対象とした. 来院時重症度の 評価には Glasgow Coma Scale（GCS）を基準としたわ

千葉県救急医療センター脳神経外科／干261-0012 千葉市美浜区磯辺 3-32-1〔連絡先：佐藤 章〕

Address reprint requests to: Akira Satoh, M.D., Neurosurgical Department, Chiba Emergency Medical Center, 3-32-1 Isobe, Mihama-ku, Chiba-shi, Chiba 261-0012, Japan 
れわれの grading (grade $1, \mathrm{II}=\mathrm{GCS} 15$, grade $\mathrm{IIIa=}$ GCS 14 , grade IIIb $=$ GCS $13 \sim 10$, grade IV $=$ GCS 9 $\sim 6$, grade $V=G C S 5 \sim 3)$ を用い16), 予後は退院時の Glasgow Outcome Scale(GOS) で評価した. 統計学的検 討には, $\mathrm{t}$ 検定, Mann-Whitney 検定を用いた。

\section{重症＜も膜下出血症例の PBD}

\section{1 狭義のPBD}

$\mathrm{SAH}$ によって生ずるPBD の本態とはなんであろう か.一言で定義するのは困難であるが, $\mathrm{SAH}$ と同時に生 ずる狭義の PBD は，きわめて短時間内に起こる急激な 頭蓋内圧 (ICP) の上昇に基づく global cerebral ischemia であろうと予想される4)6)12). 重症患者の多くが 発症と同時に意識を失い，しばしば全身痙卛を合併する ことも global ischemiaの結果と考えれば理解しやす い. 発症時の動脈性出血が停止すると, 髄液の shift など の代償機転により，ICP は徐々に低下していったん平衡 状態となる。この時点での ICP が非常に高ければ脳機能 の回復は悪く,臨床的にも poor grade と評価されること になる。しかし, global ischemia からの回復には多少時 間を要する場合も多いので，初期症状が悪くても，少な くとも 12 時間はあきらめることなく ICP コントロール を主体に手を尽くして経過を見守るべきであろう12)。 global ischemia の程度が高度である最重症例では, 虚血 障害は回復不能となり，12 時間以後の follow-up CT で 多発の脳梗塞巣が確認される場合の予後は絶対不良であ る10)11). 重症例での臨床評価の基本的問題は, この global ischemia からの回復過程のどの時点で評価して いるのかということにある。すなわち，脳機能回復の不 十分な早期に評価すれば症状を重くとりすぎることにな り, 治療適応内まで回復可能な患者を適応外としたり, 逆に治療成績が実際より良好であるかのように考元てし まう危険がある，また，回復を待ちすぎると，水頭症， 脳浮腫などの進行による症状悪化や，致命的な再出血を

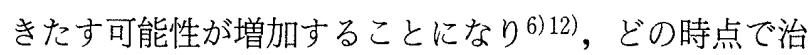
療方針を決定するのかについては，case by case の的確 な判断が要求される。

\section{2 広義の PBD}

脳機能の回復を悪くさせる要因としては, 狭義の PBD の他に, 脳内出血, 脳室内出血, 急性水頭症, 脳浮腫な どがあり4)12116)19), SAH とこれらの二次的脳障害を含め て広義の PBD と定義されよう。二次性損傷を合併した 症例での臨床評価はさらにむずかしい。例えば高度の
SAH に脳内出血, 急性水頭症を合併した症例では, 脳機 能は global ischemia からの回復と, 脳内出血による固 定した症状，水頭症および脳浮腫の進行による緩徐な症 状悪化などによる複雑な総和としてある．治療方針を決 定するには, global ischemia がぞの程度回復可能である か，血腫による固定症状の予後はどの程度期待できるか などを病歷, 臨床症状, 画像情報などから総合的に判断 する必要がある。

われわれの症例で PBD の状態を検討した結果でも， 重症になるほど正中偏位をきたす程度の脳内血腫や，急 性水頭症を伴う脳室内出血の合併の比率は高くなるが (Fig. 1)，そのような二次的脳損傷を伴わない症例も各 gradeで少なからず存在し16), 重症例における PBD が 画像上に認められる出血や水頭症だけではなく, global ischemia を含む多様な脳障害によって生じ得ることが わかる，また，最重症例である grade $\mathrm{V} に$ にける二次的 脳損傷としての脳内出血の比率が, 基本的に grade IV と異ならないことも，両群における予後の決定的な差を 考えると，重症度を決定する要因としての global ischemia の重要性を示唆しているものと思われる（Fig.1 左図).

\section{<も膜下出血急性期交感神経緊張 による全身的反広}

\section{Sympathetic storm と血中 catecho-} lamines

SAH 重症例では, 発症直後から sympathetic storm (or surge)とよばれる交感神経の過剩緊張状態が生 (゙9) 17) 20)，全身臟器に影響を及添す1)2110)17)。呼吸・循環 器系に関しては，肺水腫（自験例1,176例中129例，11.0 $\%$ ), 無呼吸 (110 例, 9.4\%), 重症不整脈 (VT, VF 23 例， $2.0 \%$ ), 心筋虚血 (23 例， $2.0 \%$ ) など, 生命に危険 を及活す可能性のある症状をきたす場合も少なくない。 無呼吸発作，心室性不整脈沉つては突然死の原因の一 つとしても注目されはじめている12)10118)。このような SAH 特有の全身性の反応は稀ならず経験するが，超急 性期に全身的にどのような病態として経過していくのか についての詳細な報告は少ない. 実際に来院時の血中 epinephrine (EP), norepinephrine (NE) 值を測定してみ ると, これらの血中 catecholamines $(\mathrm{CA})$ は発症直後よ り高值をとり,その後 24 時間以内に急速に正常化してい くことが確認された（Fig. 2A). 来院時重症度別にみて も, grade の悪いほど高值をとるが, 各 grade ごとにみる と,やはり初期高值から 12 時間以内に正常化に向かうこ 


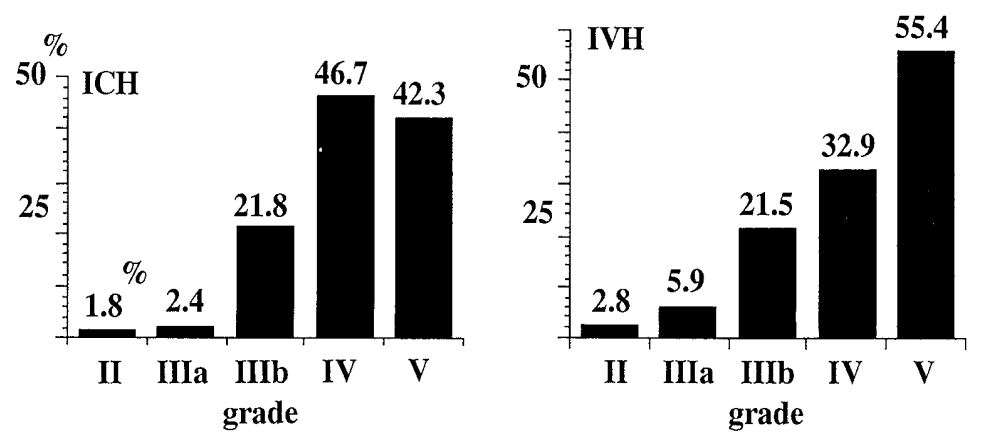

Fig. 1 The incidence of ICH and IVH at each grade

The incidence of these insults is higher in the group of higher grade. There are many cases however, where severe neurological symptoms are manifested without these hemorrhagic complications. There must be other pathology like ischemic damage which cause a (so-called) "primary brain damage".

$\mathrm{ICH}$ : intracerebral hemorrhage IVH: intraventricular hemorrhage
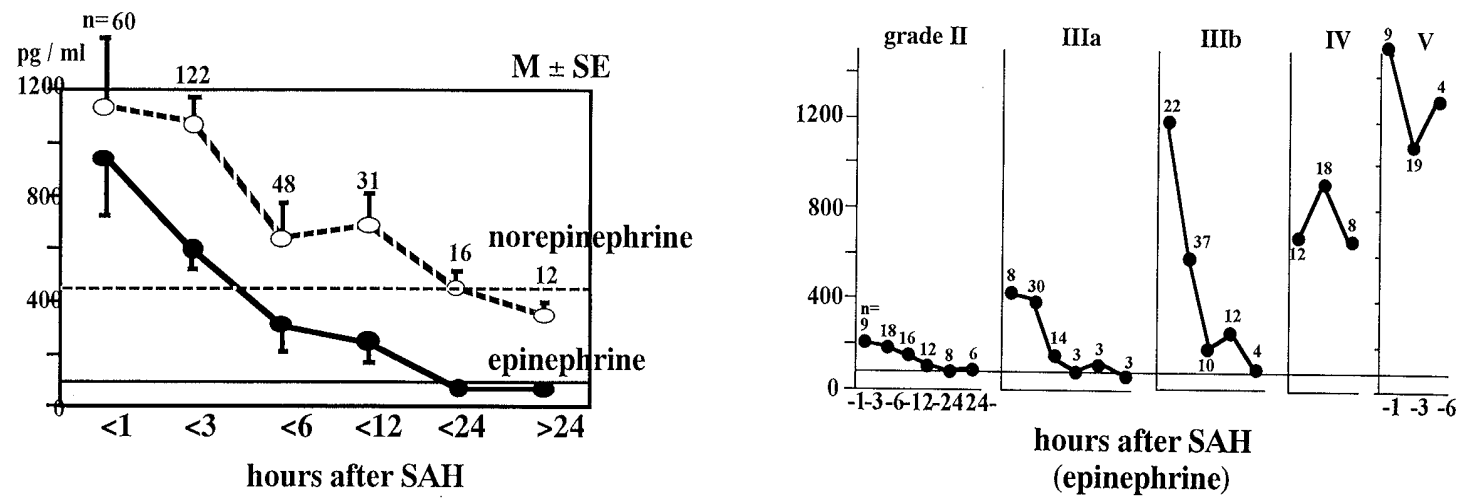

$\underline{\mathbf{A} \mid \mathbf{B}}$

Fig. 2 Change of serum catecholamine level after SAH

$\mathbf{A}$ : Serum levels of epinephrine and norepinephrine are extremely elevated immediately after the onset of $\mathrm{SAH}$ and return to normal within 24 hours.

B : This pattern of rapid elevation and decline is present at each grade though the mean level is higher at higher grades. Note that at Grades IV and V there is a tendency to retain an elevated catecholamine level for up to 6 hours.

とがわかる. grade IV, Vの重症例では高值が持続する 傾向も認められた（Fig. 2B)。このように sympathetic storm は, 発症後数時間以内の超早期に生じ, 12 時間以 内に注ぼ正常化するという急速な経過をたどるため，呼 吸・循環器系の動態がきわめて不安定な患者では，12 時 間は全身管理を優先させ，病態の落ち着くのを待ったう えで頭蓋内病変の治療を考慮した方が安全である場合も 多い.

\section{Stress index}

以上の上うに，急性期における全身的な臟器反忘の原 因である交感神経緊張の状態を正確に把握することは, 治療および病状の経過予測のうえで重要となってくる. しかし，実際に EPや NE などの血中濃度を短時間内に 測定することはむずかしく，具体的な評価方法がない。
一方, くも膜下出血急性期には, しばしば血清カリウム 值 $\left(\mathrm{K}^{+}\right)$が低下し, 血糖値 $(\mathrm{BS})$ が上昇することはよく知 られており，これらの值の急激な変動が主として $\beta-$ receptor を介する交感神経系の活性によることも実験 的に説明されている ${ }^{13)}$ 。そこで, BSを $\mathrm{K}^{+}$で除した值を stress index $\left(\mathrm{SI}=\mathrm{BS} / \mathrm{K}^{+}\right)$として表現すると, SI も CA 類とまったく同様に重症度に比例して発症直後に高值と なった後, 急速に正常化していく経過をとることがわか る (Fig. 3). 実際に発症後数時間の超急性期には, SI と 血中 CA 值は有意な相関 (発症後 3 時間での NE と SI, $r=0.664, p<0.01)$ を示し, 神経原性肺水腫, 心室性不 整脈, 心筋虚血などの重篤な呼吸・循環器系合併症例で は, 非合併例と比べて有意に SI が高值であった (Fig. 4). このように，SI という簡単な指標を算出することで，ど この施設でも即時に測定できる $\mathrm{BS}, \mathrm{K}^{+}$の值から, 急性 

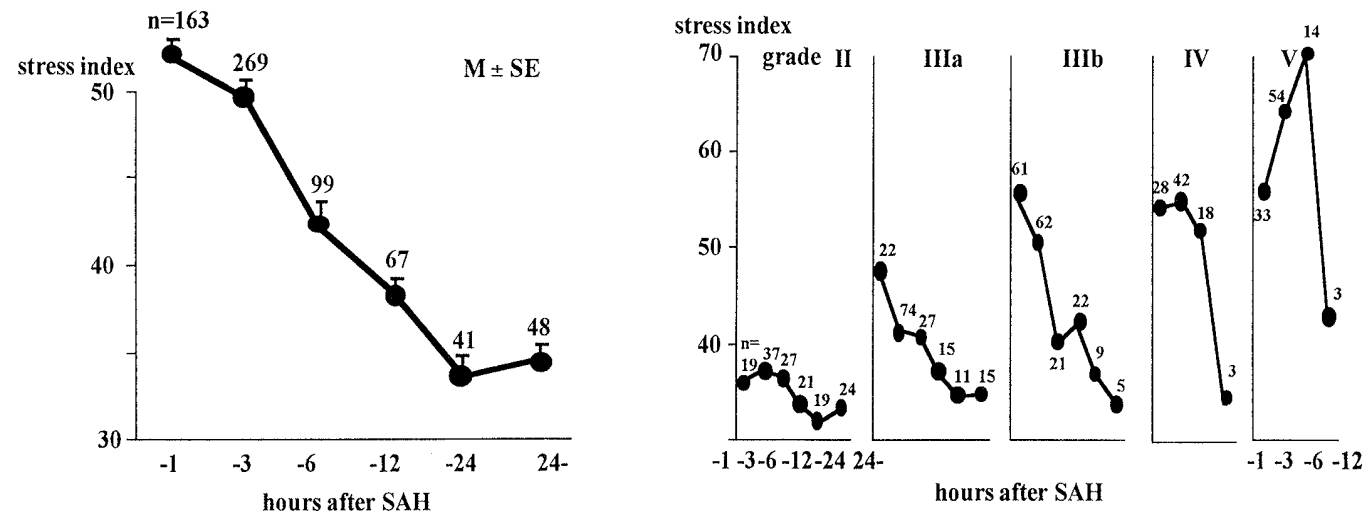

$\underline{\mathbf{A} \mid \mathbf{B}}$

Fig. 3 Change of stress index (SI) value after SAH

A : In a manner similar to the changes of serum catecholamine levels, the SI is extremely high after a SAH and decreases quickly to a normal level within 24 hours.

B : At each grade the SI shows an elevation-decline pattern which is similar to that of the catecholamines. A retention of a higher SI value is noticeable at Grades IV and V.

期患者の交感神経系の緊張状態をある程度推測できるこ とになり17)，臨床上きわめて有用であることがわかっ た.

\section{重症くも膜下出血に伴う全身臓器障害}

前項で述べた SAH 重症例における呼吸・循環器系を 中心とした重篤な臓器機能不全状態の病理組織学的な背 景として，肺においては肺うっ血，心臟では虚血一壊死 の所見をみた報告は多い229)。また最近では，急性期の尿 細管機能障害を示唆する報告もみられ 小 $^{8}$ ，初期の sympathetic storm に伴う一過性の過度の血圧上昇，あるいは 局所の血管攣縮などにより，多くの臓器において組織レ ベルでの器質的な障害が生じていることが推測される.

\section{急性期死亡例の病理組織学的所見}

くも膜下出血急性期の全身臟器障害を検討する目的 でわれわれの施設に扔ける早期死亡例につき病理学的 所見を検討した，種々の治療や臨床経過など，くも膜下 出血以外の原因による脳，および全身臟器の組織学的変 化を避けるために, 発症後 24 時間以内の死亡例での全身 解剖 2 例, 脳のみの解剖 3 例につき病理学的所見を reviewした.

詳細については稿を改めて報告する予定であるが，原 出血部位以外の脳出血（脳幹部，小脳，反対側基底核部 など）の合併が 5 例中 4 例に認められた（Fig.5)。また， 下垂体を検索し得た 4 例全例で下垂体の実質内小出血を 認めた(Fig. 6)。全身的には，2 例とも肝藏，腎臓，脾臓， 肺にうっ血や小出血などの所見を認め，1例では大腸粘 膜下出血が確認された。くも膜下出血重症例での障害が 多臓器にわたる広範な病変をきたすことを裏づける所見

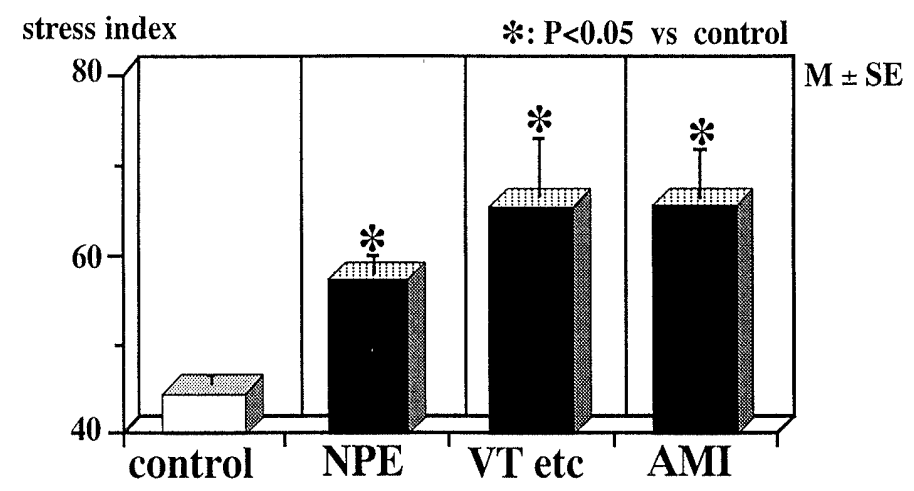

Fig. 4 Stress index and cardiopulmonary complications

The stress indexes of cases associated with lifethreatening cardiopulmonary complications such as NPE, VT, and AMI, are significantly higer than those of the control group.

NPE: neurogenic pulmonary edema VT: ventricular tachycardia (or fibrillation) AMI: acute myocardial infarction

であり，頭蓋内においても，さまざまな場所で副次出血 を生じていることが確認された。特に，下垂体の病変の 存在は humoral factor の制御障害を介して全身的にも 大きな影響を及淁すことが予想され，注目される。

\section{<も膜下出血最重症例の治療}

\section{1 grade IV と grade Vの境界はどこにおく ベきが}

歴史的かつ非常㳊有用な gradingである Hunt Kosnik 分類7) における grade Vの内容が，少なくとも 急性期手術の非適応群とみなされることから，どのよう な重症度分類を用いるにせよ，grade $\mathrm{V}$ という分類は基 本的に手術適応のない症例群としないと臨床的に混乱を 招く恐れがある。その意味で，grade IV と grade Vを どこで分けるかという問題は，急性期患者の予後を決定 


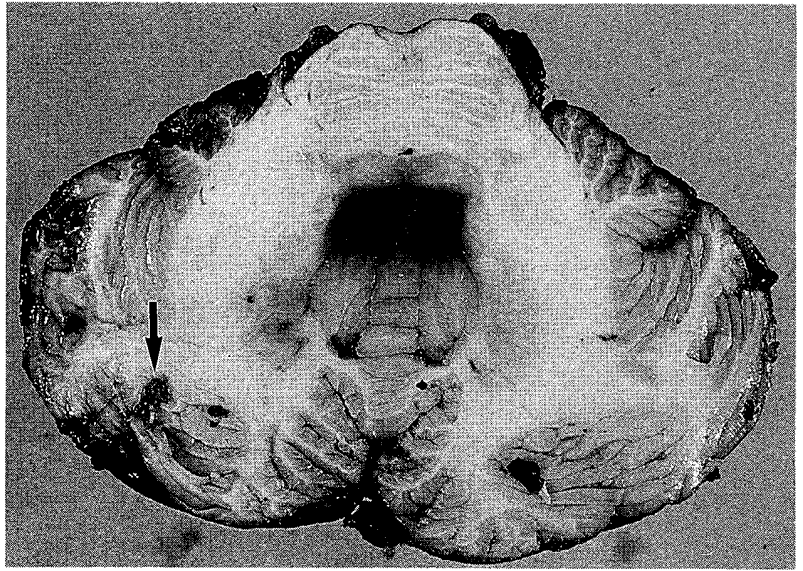

Fig. 5 Accessory hemorrhage in the cerebellum A small intracerebellar hemorrhage is observed at autopsy in a 56-year-old male (arrow). There was a huge left tempolar hematoma due to rupture of an aneurysm of the left middle cerebral artery.

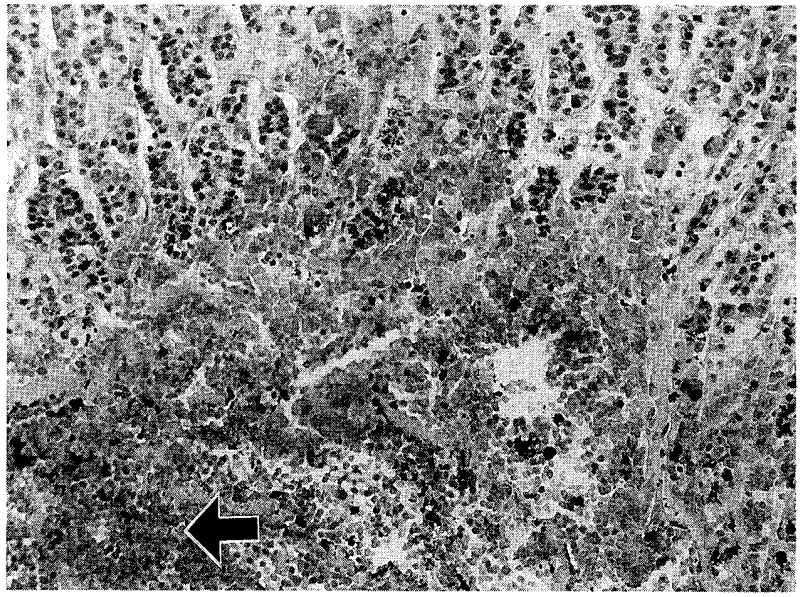

Fig. 6 Pituitary hemorrhage associated with SAH

A parenchymal hemorrhage was observed in the anterior lobe of the pituitary gland of a 78-year-old male died of bleeding from an aneurysm of the anterior communicating artery (arrow).

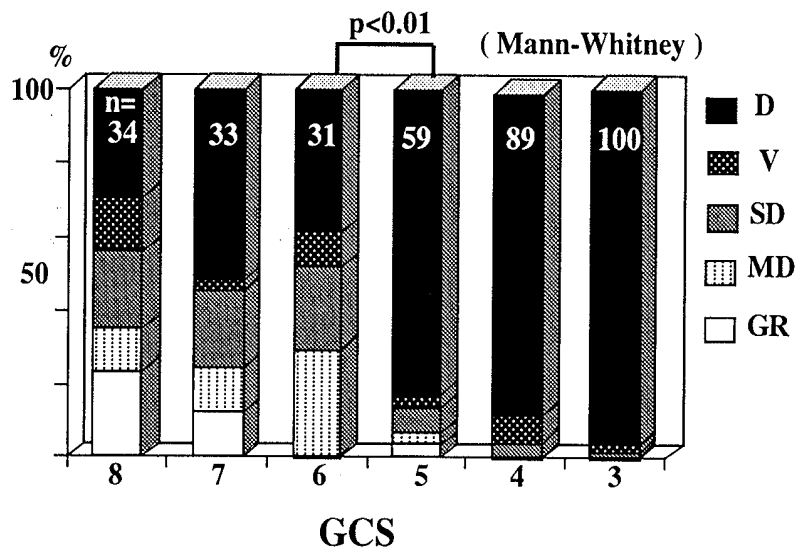

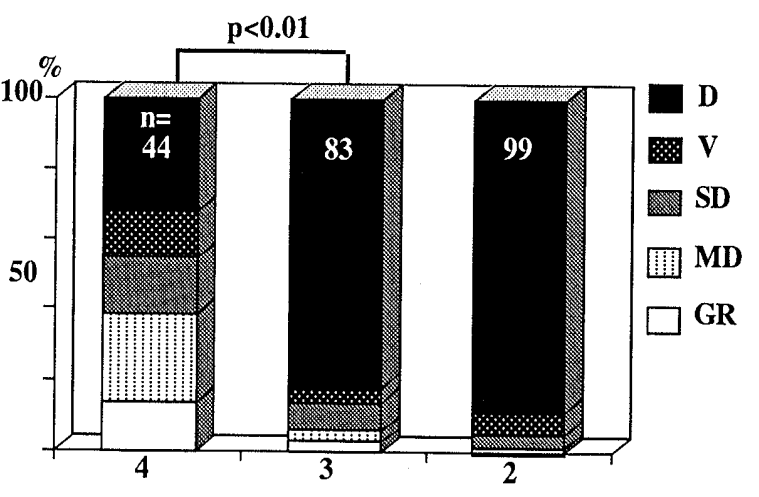

motor response

$\underline{\mathbf{A} \mid \mathbf{B}}$

Fig. 7 Outcome (GCS) of severely ill patients

A : The overall outcome of a GCS 6 group of patients is essentially the same as those of GCS 8 and 7, and a statistically significant difference is observed only between groups GCS 6 and 5. It seems reasonable therefore, that cases with GCS 6 should belong to Grade IV and GCS 5 to Grade V.

B : The difference between a GCS score of 6 and 5 is basically the difference between cases with motor responses of 4 or 3 . The former group of patients should always be treated as candidates for active treatment during the acute stage.

$\mathrm{D}$ : death $\mathrm{V}$ : persistent vegetative state $\mathrm{SD}$ : severe disability $\mathrm{MD}$ : moderate disability GR: good recovery

的に変えてしまう可能性があり, 慎重に検討されるべき であろう。

自験例における重症例の検討では，GCS sum score 8 〜3での各 GCS 間ごとの予後の差は，GCS 6〜5 間にの み有意差 $(\mathrm{p}<0.01)$ を認めた（Fig. 7A）。すなわち，急 性期症例の予後を考慮して治療適応を決定しようとする のであれば, grade IV と grade V の境界は GCS 6 と 5 の間にあり，GCS 6 は grade IV に分類するべきと結論 される，このことは，WFNSにより提唱されている分 類の急性期症例での適用には問題が多いことを意味する が3)15)，詳細は別稿に譲りたい。
この GCS 6 と 5 の差は, GCS の特性でもあるが, ほと んどそのまま motor response 4 点と 3 点の差を意味し ていることがわかる (Fig. 7B). motor 4点, すなわち sum score 6 点の症例の予後は, 良好例 $(\mathrm{GR}+\mathrm{MD})$ が 約 40\%であり, grade IV として基本的に急性期手術の 対象群として扱うべきであろうし，motor 3 点あるいは GCS 5 点の症例は grade $V$ に分類し, 原則として手術適 応外とする方針は妥当なものと思われる。

\section{2 最重症例の急性期手術適応}

われわれの施設での急性期直達手術の適応は, 70 歳以 


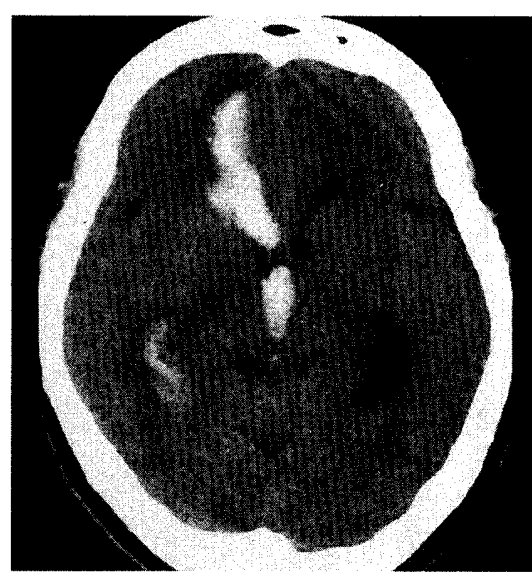

$\underline{\mathbf{A}|\mathbf{B}| \mathbf{C}}$

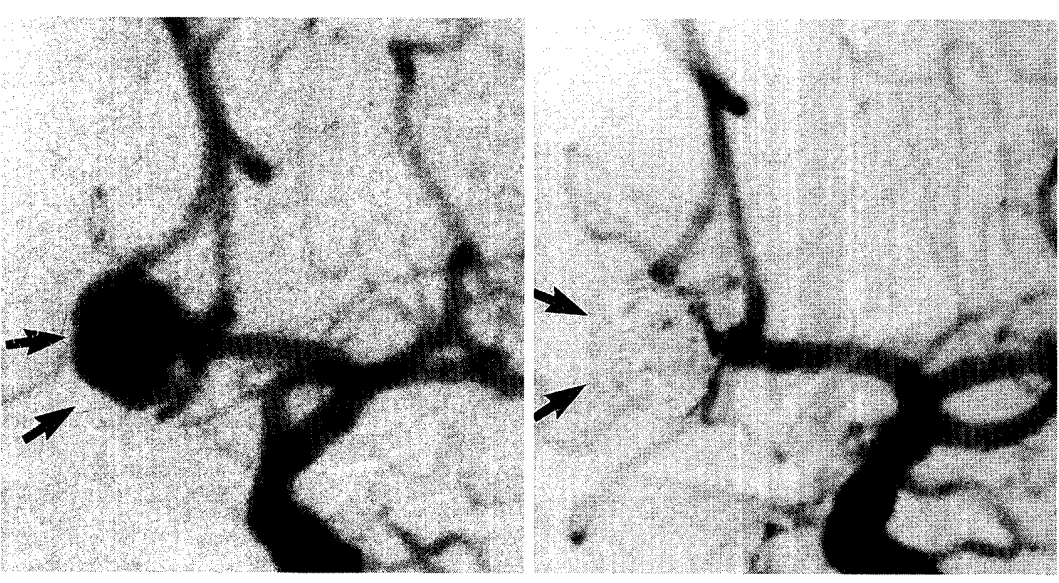

Fig. 8 A case treated by coil embolization

A 37-year-old housewife was admitted in a coma, with bilateral dilated, and fixed, pupils and a bilateral decerebrate posture.

A : A CT scan showed a SAH with an ICH and an IVH.

B, C : She underwent an emergent coil embolization for an aneurysm of the anterior communicating artery (arrows) and ventricular drainage.

She returned home 4 weeks later without any significant neurological deficit. See text for details.

下では grade IV (GCS 9〜6) まで，71 歳以上は grade III b (GCS 13〜10) までであるが，実際には 70 歳以上 の症例では PBD からの脳機能の回復の可能性を考虑し て, GCS 13 点が適応限界となることが多い.一方, 65 歳 以下の症例については, GCS 5 点, 4 点の症例中にも予 後良好例があるので12), grade V として機械的に手術適 応なしとするのではなく，個々の症例で適応を検討する 必要があると考えている。

PBD の項で述べたように, 超急性期のくも膜下出血症 例の神経症状は，必ずしも一方向的に悪化するわけでは なく, 発症直後の最悪の状態からゆっくりではあるが回 復している部分もあるので，必ず時間経過での症状の変 化を確認したうえで治療方針を決定するべきであろう。 grade IV，Vでは脳内血腫, 脳室内出血などの合併例が 多く(Fig. 1 $)^{16)}$ ，それらの二次性損傷を取り除けば，見か け上の神経症状の悪さと比べ，脳機能の回復は良好であ ることも少なくない(6)12)16)，大きな血腫を合併する症例 でも，高血圧性脳出血とは異なり，内包や基底核ではな く, 前頭葉極内や側頭葉内への出血である場合が多いの で, mass effect による症状の悪さのみに目を奪われるこ となく, 脳機能回復の可能性を考虑して手術適応を考慮 するべきであろう，両側瞳孔が散大していても，片側の 瞳孔は動脈䰹による局所症状として散大している場合も あるし，交感神経の緊張による散大もあり得る。両側除 脳硬直や，対光反射消失などの症状も常に脳へルニアの 結果として生じるわけではなく，脳室内出血による中脳 水道の拡張などによる場合は必ずしも予後不良を意味し ない.
このように，個々の症状をとれば予後絶対不良とされ るような場合でも，症状を生じている原因を推測し，あ るいは繰り返し神経症状の変化を調べ,わずかでも回復 の可能性があれば，治療適応の有無を再考する余地を残 しておくべきである ${ }^{12)}$. 現在われわれの施設では, SAH 発症後に完全な心肺停止があり, 5 分以上の蘇生術を要 した症例については, 基本的に急性期手術適応なしとし ているが，その場合でも vital signs が安定していれば， 積極的な保存的治療のもと, 12 時間後に再評価すること は当然である。繰り返し述べてきたように, SAH 重症例 に打ける臨床症状は，回復しつつあるものと，固定した もの, 悪化しているものとの複雑な混合状態にあるので, ある一時点での症状をもとに治療適応を決めたり，予後 について言及することには注意を要することを強調して おきたい。

\section{3 重症例に対する新しい治療法}

最後に, 最重症例に対するこれまでの急性期治療の限 界を乗り越える新しい武器としての coil embolization と低体温療法の可能性につき簡単に言及して打きたい。

coil embolization の利用は急性期治療に大きな变革 をもたらすものと思われる。手技的には，GDC coil を用 いた berry aneurysm に対する瘤内塞栓術5) と，解離性 動脈瘤に対する feeder あるいは解離腔の塞栓術 ${ }^{14)}$ があ る。われわれの経験では，いずれの場合も急性期の脳に 侵襲を加えることなく再出血を予防することができるた め, 脳室ドレナージ, 減圧開頭など最小限の処置を追加 することで，血管攣縮による症状悪化も少なく（自験例 
では GCS 8 点以下の連続 10 症例中 1 例のみで症候性血 管攣縮を認めた), 脳機能の回復は直達手術例よりもむし ろ良好な印象である。現在は, 高齢者, poor gradeで全 身状態も良好でない症例などに限定して施行している が，近い将来，脳内血腫などの合併のない症例での急性 期治療の主体は, 手術加ら coil embolization へと変わっ ていく可能性が高いように思われる。

\section{4 症 例}

他院でくも膜下出血を見逃され，再出血により GCS 4 点, 両側朣孔散大, 両側除脳硬直の状態で来院した 37 歳 の女性. CT 上の脳損傷が比較的少ないことと若年者で あったことから，ただちに GDC coilによる embolization と脳室ドレナージを施行したところ，数日で意識状 態の改善を認め, 後遺症なく自宅退院された。血管内治 療により脳への侵襲を避けられたことが好結果を得た一 因と思われた1例である（Fig. 8).

低体温療法については，われわれの施設では主として 術中の低体温麻酔の使用を積極的に行ってきた。術前汃 ら脳腫脹の強い症例や，巨大あるいは大型動脈瘤，動脈 瘤の形状などから血流遮断時間がある程度長びく可能性 のある症例，および脳底動脈瘤などの手術に際して，現 在までに 70 例で, 中心温度平均約 $30^{\circ} \mathrm{C}$ の中等度低体温 麻酔を使用してきた。目的は，低体温の特性である虚血 而性の増加, 脳容積の減少, 安全で安定した血圧低下作 用などを，動脈瘤手術の補助手段として利用することで あるが，術中，術後のトラブルもなく良好な結果を得て

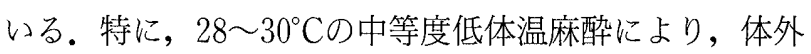
循環を用いた超低体温を使用しなくとも，30 分程度の主 要血管遮断は可能であるとの感触を得ており，今後の重 要な検討課題と考えている。持続低体温療法は, 術中に 血流遮断が長時間となり, 脳虚血が疑われる場合の術後 24 時間程度の低体温や, 脳腫脹の強い症例での ICP コ ントロール目的などで 8 例に限定して試みた。基本的に 血管攣縮を予防する効果は期待できず，いったん低体温 治療を始めると血管攣縮の危険のある時期での復温はむ ずかしく, 結局約 2 週間低体温を持続せざるを得ない状 涀となる。筆者の個人的な見解としては, 動脈溜治療に おける持続低体温療法の, 術中虚血や ICP コントロール 以外の一般的有効性には疑問を感じており, 解決すべき 課題が多いものとの印象をもっている.

\section{まとめ}

SAH 急性期においては他の脳血管障害と異なり, 発 症後の神経症状は必ずしも一方的に悪化するとは限らな
いことが重要な臨床的特徴であることを繰り返し述べて きた。そのような SAH 亿特有な病態を重症例における 治療にどのようにして生かし得るのかを探求し，わずか な機会を逃さず最善の治療を行う感性と技術が，優れた aneurysm surgeon の必要条件と信じたい。また, 超早期 の交感神経緊張に基づく全身反応への対処においては， 高度の集中治療の知識と技術を必要とするが，その意味 では, 最重症例の治療はすでに脳神経外科医単独での治 療の域を越えていると認めざるを得ないのかもしれな い. 事実, 重症の SAH 症例は脳外科施設よりも各地の救 命センターに収容されることが多くなっており，それら の施設に扔ける先進的な治療の報告も少なくない．専門 科の枠にとらわれず，動脈瘤治療の professional である 脳神経外科医が, 救急・集中治療医, 麻酔科医, 循環器 科医などと協力して, 人工呼吸器, Swan-Ganz カテーテ ル, temporary pacemaker, 心エコー, 低体温療法など の最新の医療技術の応用を総合的に managementして 治療に当たるのが，これからの SAH 重症例治療のある べき姿なのであろうことを指摘しておきたい。

稿を終えるにあたり，日常の診療で献身的な協力をいただいた千 葉県救急医療セン夕一脳神経外科の中村弘, 小林繁樹, 景山雄介, 宮田昭宏, 渡辺義郎, 神経内科の古口徳雄, 八木下敏志行, 麻酔科・ 集中治療科の中村達雄, 伊東範行, 高橋良誌の諸先生に謝意を表し たい.藤枝市立志田総合病院の篠原義賢先生にはわれわれの施設で の動脈溜治療の基礎を築かれ，多くの助言をいただいたこと，千葉 大学脳神経外科の山浦晶教授には動脈瘤治療の全般にわたり貴重 なご助言・ご指導をいただいたことを深謝する。また，病理学的検 討に関しては, 千葉県がんセンター脳神経外科, 大里克信先生と千 葉大学第一病理学教室の江沢英史先生の協力をいただき, 感謝した い.

本論文の内容の一部は, 第 17 回日本脳神経外科コングレス (1997 年 3 月 14 日, 京都) に扔いて発表した。

\section{文 献}

1) Andreoli A, di Pasquale G, Pinelli G, Grazi P, Tognetti F, Testa C: Subarachnoid hemorrhage: Frequency and severity of cardiac arrhythmias. A survey of 70 cases studied in the acute phase. Stroke 18: 558-564, 1987.

2) Doshi R, Neil-Dwyer G: A clinico-pathological study of patients following a subarachnoid hemorrhage. $J$ Neurosurg 52: 295-301, 1980.

3) Drake CG: Report of World Federation of Neurological Surgeons Comittee on a universal subarachnoid hemorrhage grading scale. J Neurosurg $\quad 68: 985^{-}$ 986, 1988 (letter).

4）藤原浩章, 高原行彦, 三平剛志, 西村卓士, 松村 浩: 破裂脑動脈瘤重症例に抢汀了予後決定因子の検討。脳卒 中の外科 $17: 214-218,1989$.

5) Guglielmi G,Vinuela F : Intra-cranial aneurysms,Guglielmi electrothrombotic coils. Neurosurg Clin North 
Am 5: 427-435, 1994.

6）橋本信夫，塚原徹也，後藤泰伸，岩間 烹，西 正吾， 鈴木 進, 秋山義典, 山本 聡, 飯原弘二, 吉村紳一, 高木康志，飯田淳一，戸高健臣，田中美千裕：重症破裂 脳動脈瘤の治療。脳卒中の外科 $23: 275-277,1995$.

7) Hunt WE, Kosnik EJ: Timing and perioperative care in intracranial aneurysm surgery. Clin Neurosurg 21:79-89, 1974 .

8）池田一美，池田寿昭，龟山佳之，杉 正俊，福田忠治， 吉田雅治：脳動脈瘤手術後の尿細管機能と血漿レニン一 アンギオテンシン系の変化について．ICUと CCU 19 : 805-811, 1995.

9）池田幸穂，中沢省三：破裂脳動脈瘤患者の血中カテコー ルアミン值の変動と予後について. 脳外 $12: 571-578$, 1984.

10）北原孝雄，増田 卓，相馬一亥：〈も膜下出血における 急死の原因の検討. 脳外 21:781-786, 1993.

11）北見公一，桜木 貢，三森研自：蘇生後脳症を伴うクモ 膜下出血の病態について．脳卒中の外科 $17: 117-122$, 1989.

12）小林延光, 上山博康, 谷川緑野, 高村春雄：重症クモ膜 下出血治療成績. 脳卒中の外科 $24: 101-106,1996$.

13) Lim M, Linton RAF, Band DM, Chir B: Continuous intravascular monitoring of epinephrine-induced changes in plasma potassium. Anesthesiology $\quad 57: 272-$ 278, 1982.
14）緒方 登, 後藤勝彌, 卯田 健: 脳動脈瘤の塞栓術. 臨 放線 39: 1230-1236, 1994.

15）佐々木雄彦，和田啓二，中川原譲二，㼼子敏夫，戸島雅 彦，伊東民雄，小林康雄，橋本 透，田中靖通，末松克 美，中村順一，松崎隆幸：破裂脳動脈瘤重症例における WFNS Grading の意義. 脳卒中の外科 17：388-391, 1989.

16）佐藤 章, 中村 弘, 小林繁樹, 兒以雄介, 平井伸二, 渡辺義郎, 篠原義賢: 重症破裂脳動脈瘤急性期の病態; 特に脳内血腫の影響について．脳卒中の外科 $17 ： 162-$ $165,1989$.

17）佐藤 章, 中村 弘, 小滝 勝, 小林繁樹, 芹澤 徹, 宮田昭宏，渡辺義郎：破裂脳動脈瘤急性期症例に対する 救急医療の意義：とくに，クモ膜下出血に伴う全身合併 症について. 救急医学 第 17 回日本救急医学会総会号, 1990, pp. 149-151.

18) Schievink WI, Wijdicks EFM, Parisi JE, Piepgras DG, Whisnant JP: Sudden death from aneurysmal subarachnoid hemorrhage. Neurology 45:871-874, 1995.

19）篠原義賢, 渡辺義郎：破裂脳動脈留急性期における脳腫 脹の検討. 脳卒中の外科 $17: 132-138,1989$.

20）吉田康成，峰岸明美，阿波根朝光，柴田憲男，楠野幸次， 石崎高志：破裂脳動脈瘤によるクモ膜下出血症例におけ る生理活性アミンの変動とその臨床的意義. Neurol Med Chir (Tokyo) $27: 946-953,1987$.

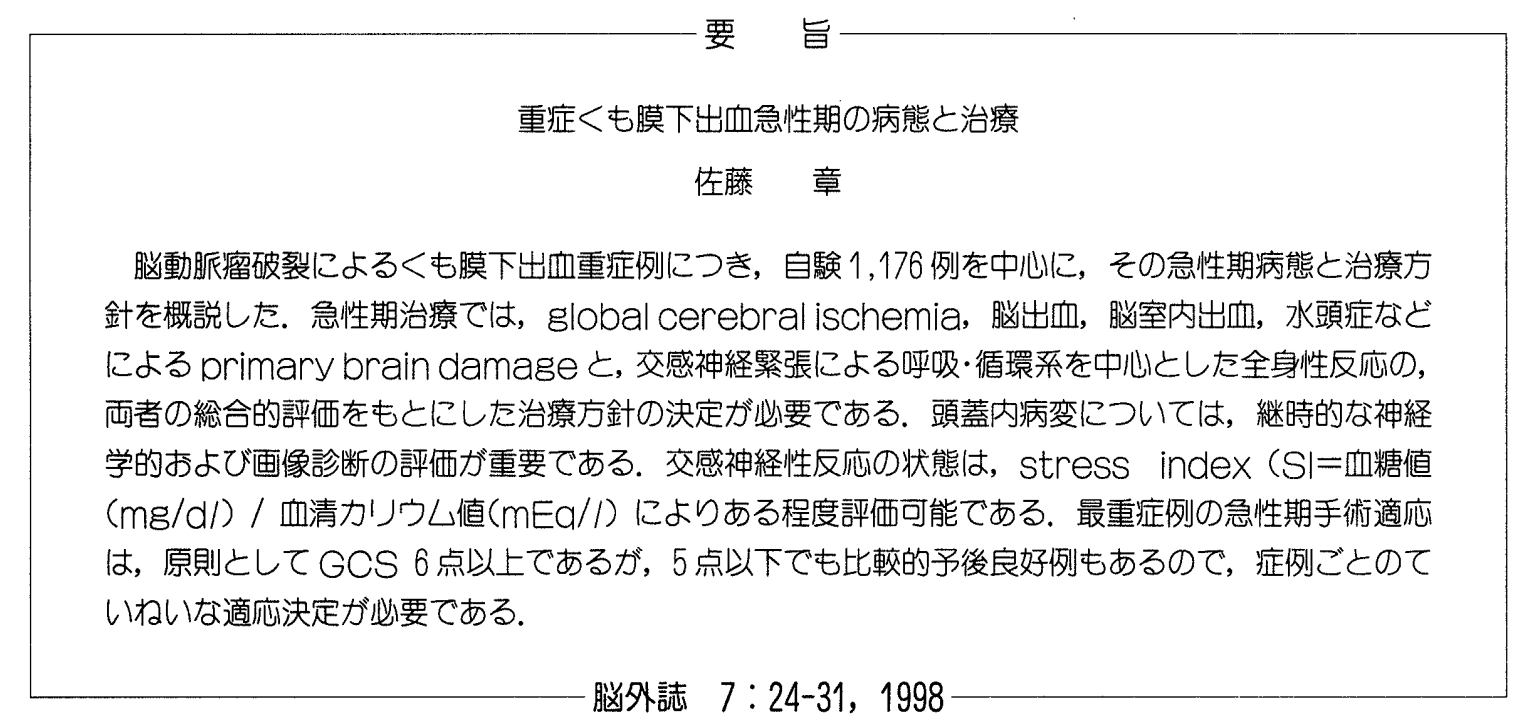

